www.volsu.ru

DOI: https://doi.org/10.15688/nsr.jvolsu.2020.1.5

UDC 631.47

LBC 20.18

\title{
DIAGNOSTICS AND SOIL FORMING CHARACTERISTICS OF ALLUVIAL-MEADOW SOILS OF GANYKH-AYRICHAY VALLEY, AZERBAIJAN
}

\author{
Vilayat Gasan ogli Gasanov \\ Institute of Soil Science and Agrochemistry of Azerbaijan National Academy of Sciences, Baku, Azerbaijan \\ Bahadur Nadzhmeddin ogli Ismailov \\ Institute of Soil Science and Agrochemistry of Azerbaijan National Academy of Sciences, Baku, Azerbaijan
}

\begin{abstract}
This study is devoted to the influence of ecological conditions on soil forming and improving the nomenclature of alluvial-meadow-forest soils in the flood plains of the subtropical forest-shrubby zone within Azerbaijan. On the basis of detailed soil mapping, the primary areal of soil units and the structure of soil cover were determined in the area of the Ganykh-Ayrichay valley. The spatial distribution of primary soil units, genetic features and diagnostic indexes (extend of bedding and development of the soil profile, thickness of the decomposedaccumulative layer, content of humus, total nitrogen, base saturation, particle size distribution, etc.) of stratified and typical suborders of alluvial-meadow-forest soils are identified. The turbidity and content of the weighted deposits of stream water is determined using regime-measurements. The weighted deposits contain a considerable amount of humus $(1.2-1.8 \%)$ and its water soluble part, total nitrogen $(0.09-0.13 \%)$ which significantly affects the morphogenetic diagnostics of the above described soils. The status of the humus content is characterized by a high activity, in which humic acid (15.3-20.8\%) and fulvic acid (16.2-22.5\%) dominate significantly, while the third fraction riches to $1.23-2.30 \%$ in the selective-group content. The ratio of $\mathrm{C}_{\mathrm{ha}}: \mathrm{C}_{\mathrm{fa}}$ reaches to $0.88-0.93$ in the leached soil profile (5.8-6.0), while reaching to 1.19-1.32 in carbonated soils (7.3-7.5). The total chemical composition of soils shows that the profile of leached soil is characterized by increasing the $\mathrm{SiO}_{2}(60.2-64.0 \%)$ content and sesquioxides $\left(\mathrm{Al}_{2} \mathrm{O}_{3}=17.6-19.5 \%, \mathrm{Fe}_{2} \mathrm{O}_{3}=8.5-10.3 \%\right)$ and the carbonated suborders contain more $\mathrm{CaO}(7.1-9.2 \%)$. The active form of iron ( $\mathrm{Fe} 3+=182-496 ; \mathrm{Fe} 2+=56-123 \mathrm{mg} 100 \mathrm{~g}$ soil) hints the insufficiency content in carbonated soils.

Key words: alluvial soils, humus, soil diagnostics, alluvial deposits, ground water, fractional composition of humus, buried horizon of soil, flood plain.
\end{abstract}

Citation. Gasanov V.G. ogli, Ismailov B.N. ogli. Diagnostics and Soil Forming Characteristics of AlluvialMeadow Soils of Ganykh-Ayrichay Valley, Azerbaijan. Natural Systems and Resources, 2020, vol. 10, no. 1, pp. 3748. (in Russian). DOI: https://doi.org/10.15688/nsr.jvolsu.2020.1.5

УДК 631.47

ББК 20.18

ОСОБЕННОСТИ ПОЧВООБРАЗОВАНИЯ И ДИАГНОСТИКА АЛЛЮВИАЛЬНО-ЛУГОВО-ЛЕСНЫХ ПОЧВ ГАНЫХ-АГРИЧАЙСКОЙ ДОЛИНЫ АЗЕРБАЙДЖАНА

\section{Вилаят Гасан оглы Гасанов}

Институт почвоведения и агрохимии национальной академии наук Азербайджана, г. Баку, Азербайджан

\section{Бахадур Наджмеддин оглы Исмаилов}

Институт почвоведения и агрохимии национальной академии наук Азербайджана, г. Баку, Азербайджан

Аннотация. Исследование посвящено влиянию экологических условий на процессы почвообразования и усовершенствование номенклатуры аллювиально-лугово-лесных почв пойм рек лесо-кустарни- 


\section{ЭКОЛОГИЯ И ПРИРОДОПОЛЬЗОВАНИЕ}

ковой субтропической зоны Азербайджана. На основе детального картирования определены элементарные почвенные ареалы и структура почвенного покрова Ганых-Агричайской долины. Выявлены различия в распространении элементарных почвенных ареалов, генетических особенностях и диагностических показателях (развитость и степень слоистости почвенного профиля, мощность перегнойно-аккумулятивного горизонта, содержание гумуса, валового азота и емкости поглощения, почвенная среда, гранулометрический состав, плотность и др.) слоистых, типичных подтипов и карбонатных аллювиально-луговолесных почв. Была определена мутность речных вод, наблюдения показали что их взвешенные наносы отличаются достаточно богатым гумусом (1,2-1,8 \%) и их воднорастворимыми частями, валовым азотом $(0,09-0,13 \%)$, что значительно влияет на морфогенетические различия описываемых почв. Гумусное состояние почв характеризуется высокий подвижностью, где во фракционно-групповом составе в большей степени доминирует первая фракция гуминовых кислот (15,3-20,8 \%) и фульво-кислоты $(16,2-22,5$ \%). Особое внимание на себя обращает весьма низкое содержание третьей фракции $(1,23-2,30 \%)$. В выщелоченных почвах (pH-5,8-6,0) отношение $\mathrm{C}_{\text {г.к }}: \mathrm{C}_{\phi . к}$ составляет 0,88-0,93, а в карбонатных почвах $(\mathrm{pH}-7,3-7,5)$ данный показатель увеличивается до 1,19-1,32. Анализ валового химического состав показал, что профиль выщелоченных почв отличается достаточно повышенным количеством $\mathrm{SiO}_{2}(60,2-64,0$ \%) и полуторных окислов $\left(\mathrm{Al}_{2} \mathrm{O}_{3}=17,6-19,5 \% ; \mathrm{Fe}_{2} \mathrm{O}_{3}=8,5-10,3 \%\right)$, а в карбонатных почвах их содержание заметно уменьшается, но величина $\mathrm{CaO}(7,1-9,2$ \%) повышается в 3-4 раза. Результаты определения подвижных форм железа $\left(\mathrm{Fe}^{3+}=182-496 ; \mathrm{Fe}^{2+}=56-123\right.$ мг на 100 г почвы) показывали, что в карбонатных почвах их содержание относительно мало.

Ключевые слова: аллювиальные почвы, гумус, диагностика почв, аллювиальные наносы, грунтовые воды, фракционный состав гумуса, погребенный горизонт почвы, пойма.

Цитирование. Гасанов В. Г. оглы, Исмаилов Б. Н. оглы. Особенности почвообразования и диагностика аллювиально-лугово-лесных почв Ганых-Агричайской долины Азербайджана // Природные системы и ресурсы. - 2020. - Т. 10, № 1. - С. 37-48. - DOI: https://doi.org/10.15688/nsr.jvolsu.2020.1.5

Введение. Как отмечает Дж. Бернал [2], значимость речных долин давно известна и оказывает влияние на развитие земледелия древнего Востока. Первые сведения о раннем земледелии приурочены к местам с благоприятным режимом увлажнения и высоким естественным плодородием почв, какими являются пойменно-аллювиальные земли. Однако генетические особенности, классификационное положение и диагностические показатели пойменно-аллювиальных почв слабо изучены по сравнению с зональными почвами. Главной причиной недостаточной изученности является динамичность процесса почвообразования и разнообразие структур почвенного покрова [8].

Важное фундаментальное значение имеет работа Г.В. Добровольского [8; 9] касаемо исследования пойменно-аллювиальных почв. Автор отмечает, что почвенный покров речных пойм отличается исключительным разнообразием в пространстве и динамичностью во времени. В связи с этим пойменно-аллювиальные почвы недостаточно изучены по сравнению с почвами водораздельных пространств, которые в таких условиях почвообразования более стабильны и закономерны.
В.А. Ковда [14] показал, что в речных поймах почвообразование начинается в условиях притока и накопления механических, химических и биогенных осадков продуктов почвообразования, содержащих органические вещества и семена растительности. Во всех природных зонах мира молодые аллювиальные отложения в течение двух-трех лет зарастают травянистой, кустарниковой и древесной растительностью и начинается формирование аллювиальных почв различной степени.

Первые сведения о характере аллювиально-лугово-лесных почв можно найти в более ранних работах Г.А. Алиева [1] и А.И. Троицкого [15]. Авторы указывают, что почвы эти распространены под пойменными низинными лесами Азербайджана (и в том числе в Ганыг-Агричайской долине), и в их формировании большая роль принадлежит илисто-песчанистым аллювиальным наносам рек и их паводковым грунтовым водам. Результаты проводимых сравнительно-географических исследований и детальное картирование дали возможность детализировать структуру почвенного покрова, классификационное положение и номенклатуру пойменно-аллювиаль- 
ных почв Азербайджана, в том числе и в Ганых-Агричайской долине и более подробно остановиться на их морфогенетической диагностике. По условиям залегания элементарных почвенных ареалов, характеру почвообразовательного процесса и по степени развития генетического профиля аллювиально-лугово-лесные почвы объекта исследования подразделяются на два подтипа: 1) аллювиально-лугово-лесные слоистые; 2) аллювиально-лугово-лесные [6; 7; 16; 17]. В основу классификации и номенклатуры аллювиально-лугово-лесных почв положены идеи В.А. Ковды [14], Г.В. Добровольского [8; 9], а также «Классификация и диагностика почв CCCР» [13], Мировая реферативная база (WRB) [18], «Классификация и диагностика почв России» [12].

Аллювиально-лугово-лесные почвы достаточно широко распространены под высокобонитетными низинными пойменными лесами в Ганых-Агричайской долине и отличаются благоприятным режимом увлажнения, субтропическим климатом и высоким естественным плодородием, но при этом отсутствют комлпексные исследования почв речных долин Азербайджана, в том числе Ганых-Агричайской долины. В связи с этим целью исследования стало: изучение влияния экологических факторов на процессы почвообразования и усовершенствование номенклатуры аллювиально-лугово-лесных почв пойм рек лесо-кустарниковой субтропической зоны Азербайджана.

Объект исследований и методика. По данным Б.А. Будагова [3], Ганых-Агричайская долина имеет площадь более 200 тыс. га, в геоморфологическом отношении она состоит из конусов выноса крупных горных рек (Белоканчай, Катехчай, Талачай, Курмухчай, Шинчай и др.) южного склона Большого Кавказа. Рельеф конусов выноса горных рек делится на верхние, средние, периферийные и межконусные части понижений. Верхняя и средняя части имеют значительный наклон и дренаж. Верхняя и средняя части были сформированы из валунногалечниковых аллювиально-пролювиальных и супесчанно-суглиннистых бескарбонатных аллювиальных отложений, формирующихся из продуктов выветривания кислых осадоч- ных горных пород. Периферийные части конусов выноса занимают пониженные формы рельефа, где уровень грунтовых вод колеблется в пределах 0,5-1,5 м, и в весенние, осенние периоды года местами выклиниваются к поверхности. Почвообразующие отложения преимущественно состоят из глинистых, местами слабокарбонатных аллювиальных отложений. В объекте исследования значительные площади занимают поймы и низкие террасы $(0,5-3,0$ м) р. Ганых и Агричай. Поверхность пойменной полосы и низких террас характеризуются упорядоченными формами рельефа, на которых распространены прирусловые, центральные и притеррасные части. Почвообразующими породами на низких террасах и поймах служат современные супесчанно-суглинистые и глинистые карбонатные аллювиальные отложения. Для них характерны оглеение, резкая слоистость, наличие прослоек песка. В зависимости от характера микрорельефа уровень грунтовых вод колеблется от $0,5-1,5$ м до 2-3 м. Грунтовые воды слабо минерализованы $(0,5-2,0$ г/л).

Климат Ганых-Агричайской долины имеет типичные переходные черты между лесной (южный склон Большого Кавказа) и степной (Ширакское степное плато) зонами, где годовое количество осадков (625-800 мм) равнымих испаряемости. Максимальное количество атмосферных осадков наблюдается как весенний, так и осенний периоды, а в летние месяцы резко уменьшается, среднегодовая температура воздуха составляет $12,1-13,2^{\circ} \mathrm{C}$.

Растительный покров представлен низинными лесами с преобладанием тополя белолистки, ореха грецкого, ольхи, дуба, граба, ивы, шелковицы, кустарника и с обилием лиан. Среди низинных лесов широко распространена луговая и лугово-болотная растительность.

Сложность условий почвообразования и крайнее разнообразие почвенного покрова аллювиальных равнин и речных пойм требуют детального исследования почв. Для полевых работ с почвой был использован метод - «ключевой участок». На объекте исследования (2015-2016 гг.) были выбраны 2 характерных участка площадью 10 


\section{ЭКОЛОГИЯ И ПРИРОДОПОЛЬЗОВАНИЕ}

15 га, в каждом из которых заложено более 10 почвенных разрезов на глубине 1,0-1,5 м и составлены их почвенные карты в масштабе 1:2000. Образцы почв подвергали следующим анализам: определение гранулометрического состава - методом растирания с раствором пирофосфата натрия, определение содержания гумуса и азота по методу И.В. Тюрина; выявление поглощенных катионов по Гедройцу; водородный показатель (рН-метримилливольтметр $\mathrm{pH}-340$, Россия); содержание $\mathrm{CO}_{2}$ карбонатов-кальциметром; определение валового состава почв классическим методом по руководству Е.В. Аринушкиной; определение фракционного и группового состава гумуса - по И.В. Тюрину в модификации В.В. Пономоревой и Т.А. Плотниковой.

Пробы для определения качества речных вод, мутности и стока взвешенных наносов по 7 пунктам, брались в весенние и летние периоды в течение 2015-2016 гг. с помощью батометр-бутылка (ГР-16, Россия).

Анализ влажности почвы, включал в себя определение содержания в ней растворимых в $1 \mathrm{H} \mathrm{H}_{2} \mathrm{SO}_{4}$ закиси и окиси железа (по К.В. Веригиной). Навеска почвы для определения содержания окиси и закиси железа бралась из генетических горизонтов в состоянии естественной влажности. Определение закиси железа $\mathrm{Fe}^{2+}$ и $\mathrm{Fe}^{3+}$ проводилось колориметрическим методом. Анализ воднорастворимого перегноя проводился по методике И.В. Тюрина, так же при проведении исследования (конец мая 2015 г.) фиксировалась температура почв. Аналитические данные исследований были статистически обработаны по методу Ю.Г. Дмитриева.

Результаты и обсуждение. Аллювиально-лугово-лесные слоистые выщелоченные почвы в основном распространены в средней части конусов выноса горных рек, в также развиваются в условиях периодического поверхностного (паводкового) и грунтового увлажнения с хорошо развитой лесной растительностью. Приурочены они, преимущественно, к слабонаклонным элементам рельефа, где уровень грунтовых вод по сезонам года колеблется от
1,0 до 2,0 метров. Под лесным войлоком формируется относительно слаборазвитый маломощный перегнойно-аккумулятивный горизонт (АY $=15-20$ см $)$, с серовато-буроватой окраской, непрочной комковато-пластинчатой структурой. Ясно выражены глееватые признаки в средних и нижних горизонтах. Заметная слоистость и частые явления залегания гумусированных горизонтов $\left(\mathrm{AY} \mathrm{g}_{\mathrm{g}}^{\mathrm{h}}=0,8-1,3 \mathrm{M}\right)$ являются характерными морфологическими признаками для описываемых почв. Верхние полуметровые части этих почв отличаются суглинистым гранулометрическим составом $(<0,01 \mathrm{Mm}=28,4$ $37,6 \%,<0,001 \mathrm{mм}=3,9-5,5 \%)$. Почвообразующие аллювиальные отложения были охарактеризованы довольно легким гранулометрическим составом $(<0,01 \mathrm{Mm}=11,4$ $22,0 ;<0,001 \mathrm{мм}=2,8-5,9 \%)$. Профиль почв характеризуется наименьшей плотностью

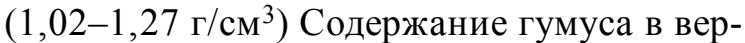
хних горизонтах составлял $3,2-4,0 \%$ a с глубиной резко уменьшался до $0,8-1,3 \%$, но в погребенных гумусированных горизонтах $\left(\mathrm{AY}_{\mathrm{g}}^{\mathrm{h}}=0,8-1,2 \mathrm{M}\right)$ возрастал до 2,1-2,8 \%. Количество общего азота в гор. $\mathrm{AY}=0,18$ $0,23 \%$. Отношение $\mathrm{C}: \mathrm{N}$ изменялось в пределах 7,3-9,0. Исследуемые слоистые почвы характеризовались выщелоченностью из-за карбонатов всего почвенного профиля. Сумма обменных оснований сравнительно невысокая и составляет 13-17 моль / 100 г почвыв гор. АY, далее с глубиной наблюдается постепенное падение до 10-12 м. экв. Обычно в нижних залеганиях гумусированных горизонтов $\left(\mathrm{AY}_{\mathrm{g}}^{\mathrm{h}}\right)$ ее величина заметно увеличивалась до 14-18 м. экв. Кислотность почвенной среды была слабокислой $(\mathrm{pH}=$ 5,8-6,4) (см. табл. 1).

Для аллювиально-лугово-лесных слоистых выщелоченных почв характерно следующее строение почвенного профиля: AO-AY-A/B-B/C ${ }_{\mathrm{g}}-\mathrm{AY}_{\mathrm{g}}^{\mathrm{h}}{ }_{\mathrm{g}} \mathrm{C}_{\mathrm{g}}$. Как отмечают многие исследователи по результатам проведенных наблюдений, слоистые почвы часто подвергаются паводковым и селевым явлениям горных речных вод, где мутность и их качественные показатели оказывают значительное влияние на процессы почвообразования. 
Особенности почвообразования и диагностика аллювиально-лугово-лесных почв Ганых-Агричайской долины

Таблица 1

Основные диагностические показателиаллювиально-лугово-лесных почв

\begin{tabular}{|c|c|c|c|c|c|c|c|c|c|c|c|}
\hline \multirow{2}{*}{$\begin{array}{c}\text { № } \\
\text { pa3- } \\
\text { peза }\end{array}$} & \multirow[t]{2}{*}{$\begin{array}{l}\text { Горизонт, } \\
\text { глубина, см }\end{array}$} & \multirow{2}{*}{$\begin{array}{c}\Gamma y- \\
\text { мyс, } \\
\%\end{array}$} & \multirow[t]{2}{*}{ Азот, \% } & \multirow[t]{2}{*}{$\underset{\%}{\mathrm{CaCO}_{3}}$} & \multirow{2}{*}{$\begin{array}{c}\mathrm{pH} \\
\text { вод. } \\
\text { сус. }\end{array}$} & \multicolumn{3}{|c|}{$\begin{array}{c}\text { Поглощенные } \\
\text { катионы, } \\
\text { моль / } 100 \text { г почвы }\end{array}$} & \multicolumn{2}{|c|}{$\begin{array}{c}\text { Гранулометри- } \\
\text { ческий состав, } \\
\%, \text { мм }\end{array}$} & \multirow[t]{2}{*}{$\begin{array}{c}\text { Плот- } \\
\text { ность, } \\
\text { Г/ } \mathrm{cm}^{3}\end{array}$} \\
\hline & & & & & & $\mathrm{Ca}$ & $\mathrm{Mg}$ & $?$ & $<0,001$ & $<0,01$ & \\
\hline 1 & 2 & 3 & 4 & 5 & 6 & 7 & 8 & 9 & 10 & 11 & 12 \\
\hline \multicolumn{12}{|c|}{ Аллювиально-лугово-лесные выщелоченные } \\
\hline \multirow{7}{*}{3} & $\mathrm{AO} 0-2$ & \multicolumn{10}{|c|}{ Лесная подстилка } \\
\hline & AU' 2-10 & 9,13 & 0,43 & нет & 6,0 & 18,3 & 5,8 & 23,1 & 9,64 & 39,88 & 1,08 \\
\hline & AU" $10-23$ & 2,95 & 0,14 & - & 5,8 & 15,7 & 5,7 & 21,4 & 17,68 & 42,48 & 1,20 \\
\hline & Bg 23-46 & 1,66 & 0,10 & - & 5,8 & 12,9 & 3,9 & 16,8 & 10,60 & 32,44 & 1,32 \\
\hline & CIg 46-78 & 0,52 & Не опр. & - & 6,2 & 9,3 & 2,6 & 11,9 & 7,56 & 26,80 & 1,29 \\
\hline & $\mathrm{AY}_{\mathrm{g}}^{\mathrm{h}} 78-105$ & 2,55 & - & - & 6,0 & 15,4 & 4,1 & 19,5 & 14,88 & 34,36 & Не опр. \\
\hline & CIIg 105-138 & 0,91 & - & - & 6,4 & 6,9 & 2,5 & 9,4 & 0,96 & 10,04 & - \\
\hline \multirow{7}{*}{6} & AO $0-3$ & \multicolumn{10}{|c|}{ Лесная подстилка } \\
\hline & AU' 3-15 & 7,55 & 0,31 & нет & 6,2 & 19,8 & 5,9 & 25,7 & 11,04 & 42,84 & 1,12 \\
\hline & AU" $15-28$ & 6,00 & 0,25 & - & 6,0 & 16,5 & 4,8 & 20,3 & 15,40 & 47,80 & 1,25 \\
\hline & Bg 28-56 & 3,49 & 0,18 & - & 6,1 & 13,4 & 4,2 & 17,6 & 11,80 & 38,56 & 1,34 \\
\hline & $\mathrm{B} / \mathrm{C} 56-85$ & 1,29 & Не опр. & - & 6,2 & 10,2 & 3,8 & 14,0 & 4,08 & 22,80 & 1,26 \\
\hline & $\mathrm{AY}_{\mathrm{g}}^{\mathrm{h}} 85-108$ & 2,34 & - & - & 5,9 & 15,3 & 5,4 & 20,7 & 12,00 & 38,76 & Не опр. \\
\hline & Cg 108-145 & 0,67 & - & - & 6,3 & 7,2 & 3,1 & 10,3 & 4,76 & 23,64 & - \\
\hline \multicolumn{12}{|c|}{ Аллювиально-лугово-лесные слоистые выщелоченные } \\
\hline & $\mathrm{AO} 0-1,5$ & & & & & сная п & Істиј & & & & \\
\hline & AY $1,5-12$ & 3,97 & 0,23 & нет & 6,0 & 14,6 & 2,1 & 16,7 & 5,52 & 28,36 & Не опр. \\
\hline & $\mathrm{A} / \mathrm{B} 12-25$ & 2,58 & 0,21 & - & 5,8 & 12,3 & 2,5 & 14,8 & 5,36 & 23,52 & - \\
\hline 8 & $\mathrm{~B} / \mathrm{C} 25-53$ & 1,30 & 0,08 & - & 6,0 & 10,7 & 3,1 & 13,8 & 4,60 & 23,88 & - \\
\hline & CIg 53-88 & 0,86 & Не опр. & - & 6,2 & 8,6 & 2,0 & 10,6 & 0,46 & 11,08 & - \\
\hline & $\mathrm{AY}_{\mathrm{g}}^{\mathrm{h}} 88-115$ & 2,82 & - & - & 5,9 & 13,7 & 4,5 & 18,2 & 8,52 & 17,88 & - \\
\hline & CIIg 115-150 & 0,72 & - & - & 6,4 & 7,1 & 2,6 & 9,7 & 2,84 & 11,40 & - \\
\hline & & Аллю & зиально- & УГОВо-J & Іые сл & сттые & ыще & ченнь & & & \\
\hline & $\mathrm{AO} 0-2$ & & & & & сная п & дсти. & & & & \\
\hline & AY'z 2-12 & 3,16 & 0,21 & нет & 6,1 & 9,4 & 4,4 & 13,8 & 3,92 & 26,84 & 1,02 \\
\hline & A/B 12-21 & 1,84 & 0,18 & - & 6,0 & 11,6 & 2,9 & 14,5 & 3,48 & 29,80 & 1,18 \\
\hline 13 & $\mathrm{~B} / \mathrm{C} 25-53$ & 2,00 & 0,20 & - & 6,2 & 10,2 & 2,3 & 12,5 & 5,68 & 37,64 & 1,27 \\
\hline & CIg 53-88 & 1,35 & Не опр. & - & 6,2 & 7,5 & 2,4 & 9,9 & 3,12 & 22,00 & 1,25 \\
\hline & $\mathrm{AY}_{\mathrm{g}}^{\mathrm{h}} 88-115$ & 2,07 & - & - & 6,0 & 8,9 & 5,6 & 14,5 & 5,94 & 31,88 & Не опр. \\
\hline & CIIg 115-150 & 0,86 & - & - & 6,3 & 7,2 & 2,4 & 9,6 & 2,20 & 14,24 & - \\
\hline & & & АллювІ & 0-Л! & о-лес & Iе кар & HaTI & & & & \\
\hline & $\mathrm{AO} 0-2$ & & & & & нная п & стил & & & & \\
\hline & AU'ca 2-12 & 6,77 & 0,30 & 9,2 & 7,4 & 20,6 & 4,9 & 25,5 & 20,12 & 50,44 & 1,14 \\
\hline & $\mathrm{A} / \mathrm{B}$ ca $12-21$ & 1,59 & 0,12 & 10,5 & 7,6 & 11,4 & 2,9 & 13,3 & 16,08 & 30,56 & 1,28 \\
\hline 20 & $\mathrm{~B} / \mathrm{Cg} 25-50$ & 1,32 & 0,10 & 7,6 & 7,6 & 12,4 & 3,0 & 15,4 & 10,88 & 50,20 & 1,33 \\
\hline & $\mathrm{AU}_{\mathrm{g}}^{\mathrm{h}} \mathrm{ca}_{50-85}$ & 4,09 & Не опр. & 8,3 & 7,4 & 25,5 & 5,3 & 30,8 & 31,72 & 55,26 & 1,40 \\
\hline & CIgca $85-110$ & 0,93 & - & 4,4 & 7,8 & 8,6 & 5,7 & 14,3 & 10,96 & 33,84 & Не опр. \\
\hline & CIIgca 110-145 & 0,21 & - & 8,6 & 7,9 & 8,9 & 5,8 & 14,7 & 1,00 & 17,32 & - \\
\hline & $\mathrm{AO} 0-2$ & & & & & сная п & стил & & & & \\
\hline & AU'ca 2-10 & 5,39 & 0,36 & 4,1 & 7,3 & 24,7 & 4,7 & 29,4 & 24,24 & 70,04 & 1,25 \\
\hline & AU" ca 10-30 & 2,80 & 0,29 & 5,4 & 7,4 & 22,3 & 3,5 & 19,7 & 24,52 & 67,08 & 1,33 \\
\hline 15 & $\mathrm{~A} / \mathrm{B}$ ca $30-65$ & 2,10 & 0,15 & 7,6 & 7,6 & 16,2 & 3,9 & 12,8 & 23,08 & 55,12 & 1,42 \\
\hline & $\mathrm{AU}_{\mathrm{g}}^{\mathrm{h}} \mathrm{ca} 65-107$ & 3,56 & 0,28 & 4,4 & 7,4 & 15,2 & 3,9 & 20,1 & 27,84 & 73,76 & 1,36 \\
\hline & CI gca 107-130 & 1,14 & Не опр. & 12,1 & 7,9 & 5,6 & 3,7 & 9,3 & 3,76 & 12,68 & Не опр. \\
\hline & CIIgca 130-150 & 0,24 & - & 14,3 & 7,9 & 5,2 & 3,3 & 8,5 & 1,64 & 15,92 & - \\
\hline & & & альн & ГОВо- & ыые с & исты & карб & Іатны & & & \\
\hline & AO $0-2$ & & & & & сная п & стил & & & & \\
\hline & AYca 2-7 & 3,13 & 0,17 & 5,9 & 7,4 & 13,6 & 4,6 & 18,2 & 3,12 & 29,56 & 1,08 \\
\hline & $\mathrm{A} / \mathrm{Bca} 7-25$ & 1,61 & 0,11 & 3,2 & 7,6 & 13,6 & 3,5 & 17,1 & 10,84 & 41,80 & 1,30 \\
\hline 19 & $\mathrm{~B} / \mathrm{Cca} 25-48$ & 1,36 & 0,10 & 7,6 & 7,7 & 9,1 & 4,1 & 13,2 & 7,04 & 29,72 & 1,28 \\
\hline & CIg 48-65 & 0,85 & Не опр. & 4,9 & 7,7 & 7,3 & 3,6 & 10,9 & 0,76 & 16,08 & 1,25 \\
\hline & $A Y^{\mathrm{h}}{ }_{\mathrm{g}} \mathrm{ca} 65-100$ & 1,76 & - & 4,3 & 7,4 & 14,7 & 9,8 & 24,5 & 25,56 & 58,56 & Не опр. \\
\hline & CIIgca 100-140 & 0,45 & - & 8,6 & 7,8 & 7,5 & 3,2 & 10,7 & 3,28 & 31,64 & - \\
\hline
\end{tabular}




\section{ЭКОЛОГИЯ И ПРИРОДОПОЛЬЗОВАНИЕ}

Выявлено, что в горах в дождливые и талые периоды (май) мутность речных вод значительно увеличивается (3,93-9,21 г/л), а в летний период (июль) в связи со снижением атмосферных осадков, на горных территориях степень мутности воды резко понижается (0,37-1,02 г/л). Установлено, что взвешенные наносы достаточно богаты гумусом (1,5-1,8 \%), и воднорастворимыми частями $(0,035-0,013 \%)$, а также валовым азотом $(0,10-0,13 \%)$. В отличие от горных рек, взвешенные наносы р. Ганых и Агричай характеризуются слабой карбонатностью $\left(\mathrm{CaCO}_{3}=3,4-4,1 \%\right)$. Кислотность воды - слабощелочная $(\mathrm{pH}=7,3-7,5)$. Взвешенные наносы формируются из высокогумусированных горно-луговых и горно-лесных почв (табл. 2).

Аллювиально-лугово-лесные вышелоченные почвы в основном распространены в периферийных частях конусов выноса горных рек Ганых-Агричайской долины и формируются в комплексе с аллювиально-луговыми и аллювиально-лугово-болотными почвами. Они развиваются в условиях близко залегающего грунтового $(0,8-1,5$ м) увлажнения под высокобонитетными лианисто-низинными лесами. Основным источником грунтовых вод являются инфильтрационные воды речных русел, поток конусовых вод горных рек и атмосферные осадки. Под лесной подстилкой $(\mathrm{AO}=$ 0-2см) со смешанностью с луговой растительностью формируется перегнойно-аккумулятивный горизонт ( $\mathrm{AU}{ }_{\mathrm{v}}+\mathrm{AU}$ " $\left.=25-30 \mathrm{~cm}\right)$, характеризующийся буровато-коричневой окраской и ореховато-зернистой структурой. На глубине 40-50 см, окраска постепенно светлеет, сохраняя коричневатый оттенок, структура становит- ся слабо комковатой. На глубине 50 см наблюдаются сильно увеличивающиеся признаки оглеения. Содержание гумуса в верхних горизонтах составляет 6,0-9,1\%, с увеличением глубины показатель уменьшается до 0,5-0,9 \%, а в залегающих гумусированных горизонтах $\left(\mathrm{AU}_{\mathrm{g}}^{\mathrm{h}}=0,8-1,2\right.$ м) вновь возрастает до $1,6-$ $2,3 \%$. Количество общего азота в гор. AU' coставляет $0,31-0,45 \%$. Отношение $\mathrm{C}: \mathrm{N}$ в пределах 9,6-12,5, что объясняется относительно слабой степенью разложения органических остатков в почве. Сумма обменных оснований в верхних горизонтах почвы составляет 2325 моль $/ 100$ г $(\mathrm{AU}=25-30 \mathrm{~cm})$, а с увеличением глубины наблюдается постепенное падение до 12-14 моль/100 г почвы. В составе обменных оснований преобладает кальций. Профиль почв выщелочен из-за наличия карбонатов.

Гранулометрический состав описываемых почв - глинисто-суглинистый. Количество физической глины $(<0,01$ мм) в верхней части профиля колеблется в пределах от 42,8 до $50,0 \%$, а иловатые частицы $(<0,001 \mathrm{Mм})$ составляют 17,0-19,6 \%. Во всех фракциях преобладают пылеватые частицы (0,05-0,001 мм), содержание которых увеличивается к низу от 28 до 45 \%. В профиле аллювиально-луговолесных выщелоченных почв слоистость слабо выражена. Плотность почв в верхних горизонтах составляет $1,08-1,12$ г/ $\mathrm{cm}^{3}$, а с глуби-

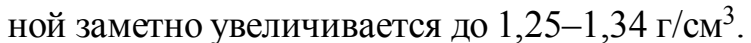
Для нормального развитого профиля аллювиально-лугово-лесных выщелоченных почв характерно наличие следующей системы генетических горизонтов: AO-AU'z-AU'-Bg-B/Cg$\mathrm{AU}_{\mathrm{g}}^{\mathrm{h}} \mathrm{-Cg}$.

Аллювиально-лугово-лесные карбонатные почвы в основном распространены в

Таблица 2

\section{Химические показатели взвешенных наносов речных вод Ганыг-Агричайской долины (в среднем 2015-2016 гг.)}

\begin{tabular}{|c|c|c|c|c|c|c|c|}
\hline \multirow{2}{*}{$\begin{array}{l}\text { Место } \\
\text { взятия } \\
\text { пробы }\end{array}$} & \multicolumn{2}{|c|}{ Мутность, г/л } & \multirow{2}{*}{$\begin{array}{c}\text { Гумус, } \\
\text { \% }\end{array}$} & \multirow{2}{*}{$\begin{array}{c}\text { Гумус водно- } \\
\text { растворимый, } \\
\% \\
\end{array}$} & \multirow{2}{*}{ Азот, \% } & \multirow{2}{*}{$\begin{array}{c}\mathrm{CaCO}_{3}, \\
\%\end{array}$} & \multirow{2}{*}{$\begin{array}{l}\text { рН вод. } \\
\text { суспен. }\end{array}$} \\
\hline & май & июль & & & & & \\
\hline Мазым-чай & 2,936 & 0,136 & 1,52 & 0,042 & 0,115 & нет & 7,3 \\
\hline Белокан-чай & 4,273 & 0,454 & 1,18 & 0,038 & 0,098 & - & 7,5 \\
\hline Катех-чай & 5,056 & 0,372 & 1,45 & 0,035 & 0,103 & - & 7,7 \\
\hline Тала-чай & 7,148 & 0,634 & 1,62 & 1,043 & 0,113 & - & 7,5 \\
\hline Курмух-чай & 9,205 & 1,023 & 1,84 & 0,051 & 0,128 & - & 7,6 \\
\hline Ганых-чай & 6,972 & 0,567 & 0,95 & 0,029 & 0,091 & 3,4 & 7,9 \\
\hline Агричай & 7,861 & 0,567 & 1,02 & 0,034 & 0,112 & 4,1 & 7,9 \\
\hline
\end{tabular}


пойме р. Ганых и формируются под низинными (тугайными) лесами в условиях со слабоминерализованными грунтовыми водами (1.02.0 г/л) и поверхностным увлажнением. Данные почвы часто подвергаются паводку, и их профиль отражает неоднократное нарушение процесса почвообразования. Уровень грунтовых вод в зависимости от характера микрорельефа и близости расположения к руслу изменяется от 0,8 м до 2,0 метров. Почвообразующей породой является современный суглинисто-супесчанный и слоисто-глинистый карбонатный аллювий р. Ганых. Под лесами хорошо развита лугово-травянистая растительность.

Для этих почв характерны значительные различия в профиле, обусловленные слоистостью и частыми явлениями залегания, явными признаками оглеения, и сплошной карбонатностью. В типичных случаях под лесным войлоком залегает темно-серый перегнойный горизонт $(\mathrm{AU}=25-30$ см), с комковато-зернистой структурой. Иногда вместо этого горизонта встречаются светлые пылевато-глинистые наносы 3-5 см.

Следует отметить, что на образование карбонатов в аллювиальных отложениях и в почвенном профиле, значительное влияние оказывают гидрокарбонатные паводковые воды рек Ганых и Агричай, которые идут со стороны Грузинской территории. Вместе с тем заметное влияние оказывают также высококарбонатные делювиальные наносы, ручьи и мелкие реки с территории степного плато (правый берег р. Ганых).

Характерной особенностью описываемых почв является пестрый гранулометрический состав, наличие глинистых и суглинистосупесчанных прослоек. Гранулометрический состав хорошо отражает особенности микрорельефа и стадии развитости почвенного профиля. Так наиболее развитые почвы (pp.15, 20) распространены в равнинных условиях рельефа и в микропонижениях. Гранулометрический состав их глинисто-тяжело суглинистый. В верхнем гор. (AU) содержится 50,4-70,0 \% физической глины (<0,01мм), из них $20,1-$ 24,0 \% падает на долю иловатых частиц $(<0,001$ мм). Относительно слаборазвитые слоистые почвы, приуроченные к прирусловой части рек, имеют суглинистый состав $(<0,001 \mathrm{Mm}=29,6-41,8 \%)$.
По содержанию и характеру распределения гумуса, по профилю аллювиально-лугово-лесные карбонатные почвы очень разнообразны. В нормально развитых почвах содержание гумуса в гор. AU составляет 5,4$6,8 \%$, с глубиной оно снижается до 1,3-1,7 \%. В залегании гумусированных горизонтов $\left(\mathrm{AU}_{\mathrm{g}}^{\mathrm{h}}=0,7-1,0 \mathrm{M}\right)$ его количество достигает до 3,6-4,1 \%. В слаборазвитых слоистых почвах содержание гумуса не превышает $3,1 \%$. Количество валового азота 0,30-0,36 \%, а в слоистых развитых уменьшается до $0,17 \%$. Закономерности по распределению карбонатов по почвенному профилю не наблюдаются, и содержание их колеблется в широких пределах $\left(\mathrm{CaCO}_{3}=5,4-14,3\right.$ \%). Карбонатные признаки морфологически не выделяются, в увлажненных условиях пропитаны почвенной массой. Емкость поглощения в верхних горизонтах сравнительно высокая (25-29 моль / 100 г почвы), в нижних суглинисто-супесчанных аллювиальных отложениях его количество резко уменьшается (8-14 м. экв.). Водородный показатель среды в верхних горизонтах слабощелочной ( $\mathrm{pH}=7,3-7,4)$, а в нижних щелочная $(\mathrm{pH}=7,8-7,9)$. Для карбонатных почв характерна следующая система генетических горизонтов: AO-AU'ca-AU'"ca-Bgca-B/Cg$\mathrm{AU}^{\mathrm{h}} \mathrm{ca}$ ca-Cgca.

Гумус верхнего горизонта аллювиальнолугово-лесных выщелоченных почв характеризуется достаточно повышенным содержанием гуминовых кислот $(26,4 \%)$, однако в составе гумуса преобладают фульвокислоты $(28,4 \%)$, что сказывается на отношении $\mathrm{C}_{\text {г.к }}: \mathrm{C}_{\phi . к}$. В слоистых почвах количество фульвокислот резко уменьшается (12,2-15,7 \%). Исключение составляет в профиле залегания гумусового горизонт $\left(\mathrm{AU}_{\mathrm{g}}^{\mathrm{h}}=0,9-1,3 \mathrm{M}\right)$, в котором незначительно возрастает их количество до 17,3-18,6 \%. Во фракционно-групповом составе гумуса значительно доминирует первая фракция гуминовых кислот $(12,2-$ $20,8 \%$ и и фульвокислот (12,2-20,8 \%). Обращаем внимание что обнаружено очень низкое содержание в третьей фракции как гуминовых $(1,2-2,3 \%)$, так и фульвокислот $(1,6-2,3 \%)$.

В карбонатных вариантах описываемых почв отношение $\mathrm{C}_{\text {г.к }}$ : $\mathrm{C}_{\phi . к}$ больше единицы $(1,2-1,3)$. Высокая подвижность гуминовых кислот в исследуемых почвах подтверждает- 


\section{ЭКОЛОГИЯ И ПРИРОДОПОЛЬЗОВАНИЕ}

ся также относительно низким содержанием гумина (31,3-45,3 \%), слабой развитостью и молодостью аккумулятивного гумусового гор. $(\mathrm{AU}-\mathrm{AY})$ и всего генетического профиля аллювиально-лугово-лесных почв. Следует отметить, что в отличие от выщелоченных разностей количество гуминовых кислот в карбонатных почвах заметно увеличивается
(24,8-33,1 \%), особенно за счет второй фракции (6,7-7,2 \%) (табл. 3).

Выщелоченные и карбонатные варианты аллювиально-лугово-лесных почв отличаются и по валовому химическому составу (табл. 4). Выщелоченные разности описываемых почв характеризуются повышенным содержанием $\mathrm{SiO}_{2}$ и полуторных окислов

Таблица 3

Групповой и фракционный состав гумусааллювиально-лугово-лесных почви (в \% от С общ.)

\begin{tabular}{|c|c|c|c|c|c|c|c|c|c|c|c|c|c|c|}
\hline \multirow{4}{*}{$\begin{array}{c}\text { № } \\
\text { pa3. }\end{array}$} & \multirow{4}{*}{$\begin{array}{l}\text { Горизонт, } \\
\text { глубина, см }\end{array}$} & \multicolumn{12}{|c|}{ С в \% от углерода гумуса } & \multirow{4}{*}{$\mathrm{C}_{\Gamma \cdot \kappa}: \mathrm{C}_{\phi . \kappa}$} \\
\hline & & \multirow{3}{*}{$\mathrm{C}, \%$} & \multirow{3}{*}{$\begin{array}{l}\text { Би- } \\
\text { тум }\end{array}$} & \multirow{3}{*}{$\begin{array}{l}\text { Декол- } \\
\text { цината }\end{array}$} & \multicolumn{4}{|c|}{ Гуминовые кислоты } & \multicolumn{4}{|c|}{ Фульвокислоты } & \multirow{3}{*}{ Гумин } & \\
\hline & & & & & \multicolumn{8}{|c|}{ Фракции } & & \\
\hline & & & & & 1 & 2 & 3 & Сумма & 1 & 2 & 3 & Сумма & & \\
\hline \multicolumn{15}{|c|}{ Аллюв иально-лугово-лесные выщелоченные } \\
\hline \multirow[t]{3}{*}{3} & AU' 2-10 & 5,20 & 6,52 & 4,43 & 20,76 & 3,30 & 2,34 & 26,40 & 22,45 & 3,60 & 2,30 & 28,35 & 43,18 & 0,93 \\
\hline & AU" $10-23$ & 1,71 & 10,98 & 5,26 & 10,01 & 2,51 & 1,60 & 14,12 & 12,47 & 2,53 & 1,18 & 16,48 & 45,21 & 0,86 \\
\hline & Bg 23-46 & 0,96 & 8,14 & 3,92 & 8,43 & 1,96 & 0,87 & 12,26 & 10,54 & 1,76 & 1,43 & 13,63 & 38,18 & 0,90 \\
\hline \multicolumn{15}{|c|}{ Аллювиально-лугово-лесные слоистые выщелоченные } \\
\hline \multirow[t]{4}{*}{8} & $\mathrm{AY}^{\prime} 1,5-12$ & 2,30 & 5,73 & 2,15 & 12,24 & 2,19 & 1,23 & 15,66 & 14,05 & 2,18 & 1,56 & 17,79 & 31,26 & 0,88 \\
\hline & $\mathrm{A} / \mathrm{B} \quad 12-25$ & 1,49 & 4,96 & 1,73 & 9,65 & 1,78 & 0,88 & 13,31 & 12,76 & 1,85 & 1,28 & 15,89 & 25,13 & 0,84 \\
\hline & $\mathrm{B} / \mathrm{Cg} 25-53$ & 0,75 & 6,12 & 1,48 & 8,50 & 1,25 & 0,75 & 10,50 & 9,30 & 1,60 & 0,64 & 11,54 & 20,54 & 0,91 \\
\hline & $\mathrm{AY}_{\mathrm{g}}^{\mathrm{h}} 88-115$ & 1,64 & 5,27 & 3,04 & 15,26 & 3,46 & 2,67 & 17,33 & 16,15 & 1,16 & 1,26 & 18,57 & 38,72 & 0,95 \\
\hline \multicolumn{15}{|c|}{ Аллювиально-лугово-лесные карбонатные } \\
\hline \multirow[t]{3}{*}{15} & AU'ca 2-12 & 3,13 & 3,56 & 5,76 & 22,19 & 7,24 & 2,64 & 33,07 & 15,83 & 6,79 & 2,15 & 24,89 & 45,34 & 1,32 \\
\hline & $\mathrm{A} / \mathrm{Bca} \quad 12-21$ & 1,62 & 1,95 & 7,35 & 13,82 & 6,65 & 2,33 & 24,80 & 11,59 & 5,53 & 1,90 & 18,62 & 45,27 & 1,23 \\
\hline & Bgca $21-50$ & 1,22 & 1,67 & 5,27 & 10,13 & 4,29 & 1,46 & 15,88 & 7,56 & 4,09 & 1,65 & 13,30 & 36,45 & 1,19 \\
\hline
\end{tabular}

Таблиц̧а 4

Валовой химический состав аллювиально-лугово-лесных почв (\% от прокаленного вещества)

\begin{tabular}{|c|c|c|c|c|c|c|c|c|}
\hline $\begin{array}{c}\text { № } \\
\text { раз. }\end{array}$ & $\begin{array}{c}\text { Горизонт } \\
\text { и глубина, см }\end{array}$ & ПІІІ & $\mathbf{S i O}_{2}$ & $\mathbf{A l}_{2} \mathbf{O}_{3}$ & $\mathbf{F e}_{2} \mathbf{O}_{3}$ & $\mathbf{P}_{\mathbf{2}} \mathbf{O}_{\mathbf{5}}$ & $\mathbf{T i O}_{2}$ & $\mathbf{M n O}$ \\
\hline \multicolumn{8}{|c|}{ Аллювиально-лугово-лесные выщелоченные } \\
\hline 3 & AU' 2-10 & 10,73 & 60,19 & 19,51 & 10,35 & 0,09 & 0,45 & 0,07 \\
& AU" 10-23 & 9,85 & 59,02 & 19,14 & 10,10 & 0,05 & 0,60 & 0,05 \\
& Bg 23-46 & 6,11 & 62,02 & 17,55 & 8,50 & 0,09 & 0,60 & 0,05 \\
& Cg 105-138 & 6,40 & 64,02 & 19,26 & 7,25 & 0,09 & 0,58 & 0,03 \\
\hline \multicolumn{8}{|c|}{ Аллювиально-лугово-лесные карбонатные } \\
\hline 15 & AU'ca 2-10 & 14,63 & 54,22 & 16,58 & 7,64 & 0,06 & 0,20 & 0,05 \\
& AU"ca 10-30 & 12,86 & 56,11 & 17,92 & 6,87 & 0,03 & 0,20 & 0,03 \\
& Bgca 30-65 & 10,83 & 57,86 & 16,28 & 7,36 & 0,03 & 0,25 & 0,02 \\
& Cgса 130-150 & 10,20 & 59,73 & 16,43 & 7,10 & 0,05 & 0,13 & 0,02 \\
\hline
\end{tabular}

Окончание таблицьь 4

\begin{tabular}{|c|c|c|c|c|c|c|c|c|c|}
\hline $\begin{array}{c}\text { № } \\
\text { pa3. }\end{array}$ & $\begin{array}{c}\text { Горизонт } \\
\text { и глубина, см } \\
\end{array}$ & $\mathrm{CaO}$ & MgO & $\mathbf{K}_{2} \mathbf{O}$ & $\mathrm{Na}_{2} \mathrm{O}$ & $\mathrm{SO}_{3}$ & $\begin{array}{l}\mathrm{SiO}_{2} \\
\mathrm{Al}_{2} \mathrm{O}_{3}\end{array}$ & $\begin{array}{r}\mathrm{SiO}_{2} \\
\mathrm{Fe}_{2} \mathrm{O}_{3}\end{array}$ & $\begin{array}{l}\mathrm{SiO}_{2} \\
\mathrm{R}_{2} \mathrm{O}_{3}\end{array}$ \\
\hline \multicolumn{10}{|c|}{ Аллювиально-лугово-лесные выщелоченные } \\
\hline \multirow[t]{4}{*}{3} & $\mathrm{AU}^{\prime} 2-10$ & 2,27 & 1,25 & 2,50 & 2,24 & 0,79 & 5,23 & 15,43 & 3,92 \\
\hline & AU" $10-23$ & 2,10 & 1,62 & 2,24 & 2,40 & 1,10 & 5,23 & 15,62 & 3,91 \\
\hline & Bg 23-46 & 2,30 & 1,48 & 2,34 & 2,06 & 1,14 & 6,62 & 20,00 & 4,63 \\
\hline & Cg $105-138$ & 2,09 & 2,25 & 1,56 & 2,10 & 0,65 & 5,68 & 23,87 & 4,59 \\
\hline \multicolumn{10}{|c|}{ Аллювиально-лугово-лесные карбонатные } \\
\hline \multirow[t]{4}{*}{15} & AU'ca 2-10 & 7,06 & 4,09 & 2,35 & 1,79 & 2,00 & 5,54 & 18,73 & 4,28 \\
\hline & AU"ca 10-30 & 8,20 & 3,90 & 2,18 & 1,94 & 1,00 & 5,31 & 21,74 & 4,27 \\
\hline & Bgca $30-65$ & 8,24 & 6,10 & 1,36 & 1,12 & 0,54 & 6,03 & 20,96 & 4,68 \\
\hline & Cgca $130-150$ & 9,17 & 5,36 & 1,02 & 0,78 & 0,35 & 6,18 & 22,61 & 4,85 \\
\hline
\end{tabular}


$\left(\mathrm{Al}_{2} \mathrm{O}_{3}=17,6-19,5 \% ; \mathrm{Fe}_{2} \mathrm{O}_{3}=8,5-10,3 \%\right)$. Однако, в суглинисто-супесчанных аллювиальных отложениях количество $\mathrm{Fe}_{2} \mathrm{O}_{3}$ уменьшается $(7,3 \%)$. Противоположный характер имеет распределение $\mathrm{SiO}_{2}$, от поверхности к нижнему горизонту, его количество повышается от 59,2 до 64,0 \%. В связи с этим молекулярные отношения $\mathrm{SiO}_{2}: \mathrm{R}_{2} \mathrm{O}_{3}$ более узкие для гор. $\mathrm{AU}(3,9)$, чем для породы $(4,6)$.

В карбонатных разностях описываемых почв содержание $\mathrm{SiO}_{2}(54,2-57,9$ \%) и полуторных окислов $\quad\left(\mathrm{Al}_{2} \mathrm{O}_{3}=16,3-17,9 \%\right.$; $\mathrm{Fe}_{2} \mathrm{O}_{3}=6,9-9,2 \%$ ) заметно уменьшается, количество силикатной формы $\mathrm{CaO}$ в 3-4 раза повышается (7,1-9,2 \%) (см. табл. 4).

Аллювиально-лугово-лесные почвы развиваются в условиях сезонного поверхностного и избыточного грунтового увлажнения. Признаки оглеения отмечаются на поверхности, а с глубиной 25-30 см появляется интенсивная сизовато-серая окраска с охристо-ржавыми пятнами, которая наблюдаются на всю глубину профиля.

Ф.Р. Зайдельман [10] отмечает, что глееобразование, несомненно, один из наиболее распространенных процессов почвообразования на земном шаре. Его изучение дает ключ к пониманию генезиса многих почв, профили которых формируются под влиянием кратковременного или устойчивого избыточного увлажнения.

Основные положения глееобразования были выявлены Г.Н. Высоцким [5]. Он установил, что наиболее характерной особенностью глееобразования является раскисление окиси железа $\left(\mathrm{Fe}^{3+}\right)$, превращение его в соединение закиси железа $\left(\mathrm{Fe}^{2+}\right)$ только при наличии органического вещества.

В работах Г.В. Добровольского [8; 9], Н.Г. Зырина, Е.И. Богословской [11] отмечается, что почвы поймы лесной зоны Русской равнины (поймы р. Клязьмы) отличаются достаточно повышенным содержанием подвижной формы железа. В аллювиально-луговых почвах $(\mathrm{pH}=6,0-6,7)$ количество окиси железа $\left(\mathrm{Fe}^{3+}\right)$ в среднем составляет 650-800 мг и закиси железа $\left(\mathrm{Fe}^{2+}\right)$ около 300-400 мг на 100 г почвы. По сравнению с аллювиально-луговыми почвами лесной зоны, исследуемые аллювиально-луговолесные почвы, отличаются пониженной ве- личиной подвижной формы железа. В профиле аллювиально-лугово-лесных выщелоченных почв подвижные окиси железа $\left(\mathrm{Fe}^{3+}\right)$ составляют 190-490 мг, закиси железа $\left(\mathrm{Fe}^{2+}\right)$ 45-123 мг на 100 г почвы, и с глубиной постепенно уменьшаются. Исключение составляет погребенный гумусовый гор. $\left(\mathrm{AU}_{\mathrm{g}}^{\mathrm{h}}=0,8-\right.$ 1,3 м), где их содержание резко увеличивается $\left(\mathrm{Fe}^{3+}-450 \mathrm{мг} ; \mathrm{Fe}^{2+}-142\right.$ мг). Их соотношение хорошо согласуется с содержанием общего и водорастворимого перегноя, где миграция и накопление железа происходит в форме органоминеральных соединений. Следует отметить, что в нижних суглинисто-супесчанных аллювиальных отложениях имеется избыточное увлажнение и преобладает окисная форма железа $\left(\mathrm{Fe}^{3+}=175-\right.$ 182 мг), что объясняется их слабой гумусированностью, а также содержанием малого количества иловато-глинистых частиц и их карбонатностью (см. табл. 5).

Как отмечают многие исследователи, в карбонатной почве обычно формируются труднорастворимые железисто-органоминеральные соединения, в результате чего значительно уменьшаются подвижные формы железа [4; 10]. Это подтверждается нашими сравнительными исследованиями, где в карбонатных вариантах аллювиально-лугово-лесных почв наблюдается относительное уменьшение подвижных форм железа $\left(\mathrm{Fe}^{3+}=165-\right.$ 312 мг; $\mathrm{Fe}^{2+}=32-75$ мг).

Заключение. Результаты исследования влияния экологических условий на процессы почвообразования и усовершенствование номенклатуры аллювиально-лугово-лесных почв пойм рек лесокустарниковой субтропической зоны Азербайджана позволяют подвести следующие итоги:

1. На основании комплексных исследований выявлены основные генетические особенности и диагностические показатели слоистых слаборазвитых и типичных аллювиально-лугово-лесных почв лесокустарниковой субтропической зоны Азербайджана.

2. Определена мутность горных речных вод и выявлен качественный состав взвешенных наносов, которые значительно влияют на формирование генетического профиля исследуемых почв Ганых-Агричайской долины. 
Содержание подвижных форм железа в аллювиально-лугово-лесных почв Ганыг-Агричайской долины

\begin{tabular}{|c|c|c|c|c|c|c|c|}
\hline \multirow{2}{*}{$\begin{array}{c}\text { № } \\
\text { pa3- } \\
\text { pe3a }\end{array}$} & \multirow{2}{*}{$\begin{array}{c}\text { Горизонты и } \\
\text { глубина, } \\
\text { см } \\
\end{array}$} & \multirow{2}{*}{$\begin{array}{c}\text { Гумус, } \\
\%\end{array}$} & \multirow{2}{*}{\begin{tabular}{|c} 
Воднораствори- \\
мый перегной \\
В \% к почве
\end{tabular}} & \multirow{2}{*}{$\begin{array}{c}\text { Полевая } \\
\text { влажность, } \\
\% \\
\end{array}$} & \multicolumn{2}{|c|}{$\begin{array}{c}\text { В мг на } 100 \text { г } \\
\text { абс. сухой почвы }\end{array}$} & \multirow{2}{*}{$\begin{array}{c}\mathbf{t}^{\mathbf{0}} \text { поч- } \\
\text { ВЫ }\end{array}$} \\
\hline & & & & & $\mathrm{Fe}^{2+}$ & $\mathrm{Fe}^{3+}$ & \\
\hline \multicolumn{8}{|c|}{ Аллювиально-лугово-лесные выщелоченные почвы } \\
\hline \multirow[t]{6}{*}{3} & AU' 2-10 & 9,13 & 0,079 & 33,7 & 123 & 496 & 18,4 \\
\hline & AU" $10-23$ & 2,95 & 0,035 & 40,5 & 79 & 403 & 18,1 \\
\hline & Bg 23-46 & 1,66 & 0,018 & 34,3 & 54 & 305 & 17,5 \\
\hline & CIg 46-78 & 0,52 & 0,013 & 22,8 & 45 & 196 & 16,9 \\
\hline & $\mathrm{AY}_{\mathrm{g}}^{\mathrm{h}} 78-105$ & 2,55 & 0,068 & 38,6 & 142 & 452 & 16,0 \\
\hline & CIIg 105-138 & 0,91 & 0,015 & 29,2 & 56 & 175 & 15,2 \\
\hline \multicolumn{8}{|c|}{ Аллювиально-лугово-лесные карбонатные почвы } \\
\hline \multirow[t]{5}{*}{15} & AU'ca 2-10 & 5,39 & 0,047 & 28,9 & 75 & 312 & 19,2 \\
\hline & AU"ca 10-30 & 2,80 & 0,032 & 32,5 & 46 & 256 & 18,5 \\
\hline & Bgca 30-65 & 1,86 & 0,026 & 27,3 & 28 & 165 & 17,9 \\
\hline & $\mathrm{AU}_{\mathrm{g}}^{\mathrm{h}}$ 65-107 & 3,56 & 0,059 & 35,8 & 87 & 314 & 17,1 \\
\hline & Cgca $107-130$ & 1,14 & 0,028 & 30,6 & 32 & 182 & 16,4 \\
\hline
\end{tabular}

3. Установлено, что гумусовое состояние аллювиально-лугово-лесных почв отличается значительной подвижностью, где по фракционному составу гуминовых кислот и фульвокислот доминирует первая фракция, отношение $\mathrm{C}_{\text {г.к }}: \mathrm{C}_{\phi . к}$ выщелоченных почв составляет $0,88-0,93$, а в карбонатных разностях увеличивается до 1,19-1,32.

4. Валовой химический состав аллювиально-лугово-лесных выщелоченных почв характеризуется достаточным количеством $\mathrm{SiO}_{2}$ и полуторных окислов, а в карбонатных разностях их содержание заметно понижается, но $\mathrm{CaO}$ увеличивается почти в 3-4 раза.

5. Выявлено, что количество подвижных форм железа по сравнению с выщелоченными вариантами в карбонатных почвах заметно понижается.

\section{СПИСОК ЛИТЕРАТУРЫ}

1. Алиев, Г. А. Почвы Большого Кавказа в пределах Азербайджанской Республики. Часть 2 / Г. А. Алиев. - Баку : Элм, 1994. - 310 с.

2. Бернал, Дж. Наука и история общества / Дж. Бернал. - М. : Изд-во иностр. лит., 1956. -367 c.

3. Будагов, Б. А. Геоморфология южного склона Большого Кавказа / Б. А. Будагов. - Баку : Изд. АН, 1973. -245 c.

4. Водяницкий, Ю. Н. Соединения железа в карбонатно-сульфатных почвах на красноцветных кембрийских породах в Южном Приангарье. / Ю. Н. Водяницкий, С. А. Щоба, О. Г. Лопатовская // Почвоведение. - 2014. - № 5. - С. 553-562.
5. Высоцкий, Г. Н. Глей / Г. Н. Высоцкий // Изб. сочинения. $-1962 .-$ Т. 2. - С. 70-91.

6. Гасанов, В. Г. Морфогенетическая диагностика и номенклатура аллювиально-луговых почв Ганых-Агричайской долины / В. Г. Гасанов, Б. Н. Исмаилов // Вестник Рязанского Государственного Агротехнол. Университета. -2016. - №2 (30). -С. 12-18.

7. Гасанов, В. Г. Почвы пойм и низинных лесов Азербайджана / В. Г. Гасанов // Морфогенетические профили почв Азербайджана. - 2004. C. $112-132$.

8. Добровольский, Г. В. Учение о почвообразовании в поймах и дельтах рек, и его значение в развитии о генетическом почвообразовании / Г. В. Добровольский // Почвоведение. - 1984. № 12. - С. 27-33.

9. Добровольский, Г. В. Почвы речных пойм центра Русской равнины / Г. В. Добровольский. М. : МГУ, 1968. $-295 \mathrm{c}$.

10. Зайдельман, Ф. Р. Процесс глееобразования и его роль в формировании почв / Ф. Р. Зайдельман М. : МГУ, 1998. $-300 \mathrm{c}$.

11. Зырин, Н. Г. Сезонные изменения в составе и свойствах пойменных почв р. Клязьмы / Н. Г. Зырин, Е. И. Богословская // Пойменные почвы русской равнины. - 1962. - С. 143-195.

12. Классификация и диагностика почв России / Л. Л. Шишов [и др.]. - Смоленск : Ойкумена, 2004.$342 \mathrm{c}$.

13. Классификация и диагностика почв СССР. / М. : Колос, 1977. -223 c.

14. Ковда, В. А. Основы учения о почвах / В. А. Ковда. - М. : Наука, 1973. - Кн. 2. - 468 с.

15. Троицкий, А. И. Почвы Закатальской зоны и их пригодность под культуру чая / А. И. Троицкий // Развитие культуры чая в Азербайджане в соче- 
тании с другими отраслями сельского хозяйства. 1957. - C. 114-146.

16. Babaev, M. P. Modern Azerbaijani Soil Classification System / M. P. Babaev, C. M. Dzhafarova, V. G. Gasanov // Eurasian Soil Science. - 2006. - Vol. 39, № 11. - P. 1176-1182.

17. Gasanov, V. G. Genetic Features and Diagnosis of Alluvial-Meadow Soils in Flood-Lands of the Khura River/V. G. Gasanov // Annals of Agrarian Science. - 2010. - Vol. 8, № 1. - P. 63-69.

18. World Reference Base for Soil Resources / Rome: Food and Agriculture Organization of the United Nations, 2015. - 193 p.

\section{REFERENCES}

1. Aliev G.A. Pochvy Bolshogo Kavkaza v predelakh Azerbaydzhanskoy Respubliki. Chast 2 [Soils of the Greater Caucasus Within the Republic of Azerbaijan. Part 2]. Baku, Elm Publ., 1994, 310 p.

2. Bernal Dzh. Nauka i istoriya obshchestva [Science and History of Society]. Moscow, Izd-vo inostrannoy liteatury, 1956. $367 \mathrm{p}$.

3. Budagov B.A. Geomorfologiya yuzhnogo sklona Bolshogo Kavkaza [Geomorphology of the Southern Slope of the Greater Caucasus]. Baku, Izd-vo. AN, 1973. $245 \mathrm{p}$.

4. Vodyanitskiy Yu.N., Shchoba S.A., Lopatovskaya O.G. Soedineniya zheleza v karbonatnosulfatnykh pochvakh na krasnotsvetnykh kembriyskikh porodakh v Yuzhnom Priangarye [Iron Compounds in Carbonate-Sulfate Soils on RedColored Cambrian Rocks in the Southern Angara Region]. Pochvovedenie [Soil Science], 2014, no. 5, pp. 553-562.

5. Vysotskiy G.N. Gley [Glay]. Izb. sochineniya [Selected Works], 1962, vol. 2, pp. 70-91.

6. Gasanov V.G., Ismailov B.N. Morfogeneticheskaya diagnostika i nomenklatura allyuvialno-lugovykh pochv Ganykh-Agrichayskoy doliny [Morphogenetic Diaqnostics and Nomenclature ofAlluvial-Meadow Soils in Ganikh-Agrichay Valley]. Vestnik Ryazanskogo Gosudarstvennogo Agrotekhnol. Universiteta [Herald of Ryazan State Agrotechnological University Named after P.A. Kostychev], 2016, no. 2 (30), pp. 12-18.

7. Gasanov V.G. Pochvy poym i nizinnykh lesov Azerbaydzhana [Soils of Floodplains and Lowland Forests of Azerbaijan]. Morfogeneticheskie profili pochv Azerbaydzhana [Morphogenetic Profiles of
Soils in Azerbaijan]. Baku, Elm Publ., 2004, pp. 112-132.

8. Dobrovolskiy G.V. Uchenie o pochvoobrazovanii $\mathrm{v}$ poymakh i deltakh rek, i ego znachenie $v$ razvitii o geneticheskom pochvoobrazovanii [The Doctrine of Soil Formation in Floodplains and River Deltas, and Its Significance in the Development of Genetic Soil Formation]. Pochvovedenie [Soil Science], 1984, no 12, pp. 27-33.

9. Dobrovolskiy G.V. Pochvy rechnykh poym tsentra Russkoy ravniny [Soils of River Floodplains of the Center of the Russian Plain]. Moscow, Izd-vo MGU, 1968.295 p.

10. Zaydelman F.R. Protsess gleeobrazovaniya i ego rol $v$ formirovanii pochv [The Process of Glee Formation and Its Role in Soil Formation]. Moscow, Izd-vo MGU, 1998. 300 p.

11. Zyrin N.G., Bogoslovskaya E.I. Sezonnye izmeneniya $\mathrm{v}$ sostave i svoystvakh poymennykh pochv r. Klyazmy [Seasonal Changes in the Composition and Properties of Floodplain Soils of the Klyazma River]. Poymennye pochvy russkoy ravniny, 1962, pp.143-195.

12. Shishov L.L., Tonkonogov V.D., Lebedeva I.I., Gerasimova M.I. Klassifikatsiya i diagnostika pochv Rossii [Classification and Diagnostics of Soils in Russia]. Smolensk, Oykumena Publ., 2004, 342 p.

13. Klassifikatsiya i diagnostika pochv SSSR [Classification and Diagnostics of Soils in the USSR]. Moscow, Kolos Publ., 1977. 223 p.

14. Kovda V.A. Osnovy ucheniya o pochvakh Kn. vtoraya [Fundamentals of the Doctrine of Soils. Book 2]. Moscow, Nauka Publ., 1973. 468 p.

15. Troitskiy A.I. Pochvy Zakatalskoy zony i prigodnost ikh pod kulturu Chaya [Soils of the Zakatala Zone and Their Suitability for Tea Culture]. Razvitie kultury chaya $v$ Azerbaydzhane $v$ sochetanii s drugimi otras-lyami selskogo khozyaystva [Development of Tea Culture in Azerbaijan in Combination with Other Branches of Agriculture]. Moscow, Izd-vo AN SSSR, 1957,pp. 114-146.

16. Babaev M.P., Dzhafarova C.M., Gasanov V.G. Modern Azerbaijani Soil Classification System. Eurasian Soil Science, 2006, vol. 39, no. 11, pp. 1176-1182.

17. Gasanov V.G. Genetic Features and Diagnosis of Alluvial-Meadow Soils in Flood-Lands of the Khura River. Annals of Agrarian Science, 2010, vol. 8, no. 1, pp. 63-69.

18. World Reference Base for Soil Resources. Rome, Food and Agriculture Organization of the United Nations, 2015. 193 p. 


\section{ЭКОЛОГИЯ И ПРИРОДОПОЛЬЗОВАНИЕ}

\section{Information About the Authors}

Vilayat Gasan ogli Gasanov, Doctor of Sciences (Agriculture), Head of "Structure of Soils Cover" Laboratory, Institute of Soil Science and Agrochemistry of Azerbaijan National Academy of Sciences, M. Ragima St. 5, AZ 1073 Baku, Azerbaijan, vilayet-hesenov@mail.ru.

Bahadur Nadzhmeddin ogli Ismailov, Ph.D. (Agrarian Sciences), Leading Researcher, "Structure of Soils Cover" Laboratory, Institute of Soil Science and Agrochemistry of Azerbaijan National Academy of Sciences, M. Ragima St. 5, AZ 1073 Baku, Azerbaijan, ibahadur@bk.ru.

\section{Информация об авторах}

Вилаят Гасан оглы Гасанов, доктор аграрных наук, руководитель лаборатории «Структура почвенного покрова», Институт Почвоведения и Агрохимии Национальной Академии Наук Азербайджана, ул. М. Рагима 5, AZ 1073 г. Баку, Азербайджан, vilayet-hesenov@mail.ru.

Бахадур Наджмеддин оглы Исмаилов, доктор философии по аграрным наукам, ведущий научный сотрудник лаборатории «Структура почвенного покрова», Институт Почвоведения и Агрохимии Национальной Академии Наук Азербайджана, ул. М. Рагима 5, AZ 1073 г. Баку, Азербайджан, ibahadur@bk.ru. 